\title{
Visiting a London library
}

\author{
By Jane Kemp \\ Circulation/Reference Libarian \\ Luther College
}

\section{A British polytechnic library on London's south side.}

\section{W} tion in CઐRL News, February 1985, to arrange visits in London area libraries during the summer, I became interested immediately. My family and I had planned to spend much of the summer in Great Britain with at least two weeks scheduled for London. Since I knew no librarians in Great Britain and had no entree to any particular libraries, this was a wonderful opportunity to receive an indepth tour.

I wrote to the executive secretary of the Association early in the spring (at least one month's notice is required) and suggested certain parameters for my visit. I requested that a visit be arranged with an academic library of a size similar to the small liberal arts college library where I am employed. I also wished to visit a highly automated library that provided some computer services to patrons. At the beginning of the summer I received word that the match had been made and was told where and when to report during my stay in London.

The library I was to visit was part of the Polytechnic of the South Bank, a technical school located on London's southern end. Peter Cousins, systems librarian, was designated as my host and guide. I was given specific instructions to exit the London Underground at the Elephant and Castle station and proceed to the library located on London Road. This was the main library for the school; two smaller branches were also located nearby.

With these instructions in mind, I emerged from the Underground only to be surrounded by groups of recent-looking brick buildings and no signs. After asking directions from several passersby, I finally found the library. I later discovered that this area of London received extensive damage during the war, which accounted for the more contemporary architecture of the school and the surrounding area.

Peter Cousins and I spent an afternoon talking and touring the library. I quickly learned that although the Polytechnic and my college library are similar in the number of volumes held (or "bookstock"), the differences between the two are marked. He began by explaining the nature of the British polytechnic, trying to relate it to a comparable American institution. Although the American community college or technical school is somewhat similar, the polytechnics found throughout Great Britain serve a more diverse population and are funded altogether differently.

The library itself was located in a building less than 10 years old. It was small for the amount of use it received and very utilitarian in appearance. The circulation was enormous by small college standards-an average of 1,167 items were issued per day during the school terms. A staggering number of overdue notices were printed as well, reflecting a relatively short check-out period for books and periodicals. Sixty percent more patrons entered the library than at our college.

The library staff was considerably larger than that of the small American college library. There were 17 professional librarians on the staff and 19 library assistants and secretaries. Duties which in my experience are routinely managed by nonprofessional staff, were performed only by professionals. Interlibrary loans and cataloging, for example, were seen as work suitable for professionals only. 
The entire library was automated with a GEAC 8000 mini-computer with 32 ports currently available. Circulation, acquisitions, and cataloging were automated. An online catalog had been in place since 1982. Online information retrieval had been offered as a service since 1983. Searches were increasing due to the librarians promoting its use among the students and faculty. Interlibrary loans were also arranged via computer and were increasing as the online information retrieval services were becoming better known.

Cousins emphasized several times through the course of our visit that automation in the library had actually increased the need for human input, contrary to popular conception. Automation "simply redeployed older library skills," as it was stated by the head of learning resources in the library's annual report.

Computers were also available for patron use and had been for a number of years. Although several of the computers were older, such as the BBC Acorn model, none had been removed because demand for them was so heavy. The librarians had been trained to help orient patrons to the computers and explain some features of their operation.

The library staff were active in issuing a number of publications ranging from bookmarks and subject lists of periodicals to accession lists and subject lists of audiovisual materials. They also published bibliographies and a Learning Resources Bulletin for the faculty. The publications were stored on WORDPAK, the word processor attached to the
GEAC mini-computer. Information was loaded directly from the online catalog onto the word processor for editing. Cousins pointed out that the publications part of the library work was seen as indispensible for informing both faculty and students about library services.

Staff development in the library was obviously a priority of the library administration. Two librarians had exchanged positions for the summer term so each could gain experience in the other's position. Librarians were encouraged to go on field trips, attend meetings and take courses to upgrade their skills. In the list of activities of librarians noted in the annual report, some of these experiences had evidently resulted in articles and papers being produced.

I came away from my library visit impressed with the way in which this library had made traditional library functions more efficient through automation. It was apparent that the library was used heavily and that the school was expected to expand. This setting seemed ideal for the sort of enhancements that automation achieves for continued effective service.

The library visit itself was an opportunity I would recommend to others who will be in the London area during the summer. It was a wonderful way to meet library staff and see a "foreign" library from the inside. My host was most hospitable, eager to answer my many questions and to ask some of his own. I hope that the Library Association will continue to offer this opportunity for guests to Great Britain.

\section{Florida State's Pepper Library offers a unique Congressional setting}

May 15, 1985, marked the formal opening of the Mildred and Claude Pepper Library in Dodd Hall on the Florida State University campus.

Claude Pepper, the 84-year-old Florida Congressman whose political career has spanned 56 years and the administrations of eight U.S. presidents, has given eloquent acknowledgement of the debt he owes his deceased wife, Mildred, for her constant support of his political career by including her name and personal papers in the Library. Congressman Pepper's extensive collection includes his official and personal papers, photographs, recordings, books, and memorabilia, that cover his years as Florida legislator in the late 1920s, as U.S. Senator during the 1930s and 1940s under Presidents Roosevelt and Truman, to his career as a U.S. Representative from the 1960 s to the present. They are still received as his political career continues, with materials on the aging his most current topic of concern.

The Library also includes the papers, memora- bilia, and paintings of Mildred Irene Webster Pepper. Together, these collections, currently over 475 feet in total volume, offer researchers the opportunity to study the lives and times of two politically active individuals.

The collection was donated to FSU as a tribute to his wife, Mildred, who spent many hours studying in Dodd Hall, built between 1924 and 1929 as the library for the Florida State College for Women, where she was a student in the 1930s. He met Mildred in Tallahassee, where the two lived for many years when he practiced law. He said that Mildred was the first to suggest that Dodd Hall would be an appropriate place for their records. Moreover, Florida State University was chosen because of Pepper's family ties to North Florida and the fact that Tallahassee is the state capital.

Florida State University has spent more than $\$ 800,000$ restoring a portion of Dodd Hall to house the Pepper Library. Downstairs, the original library's gothic-style high-ceilinged and walnut- 


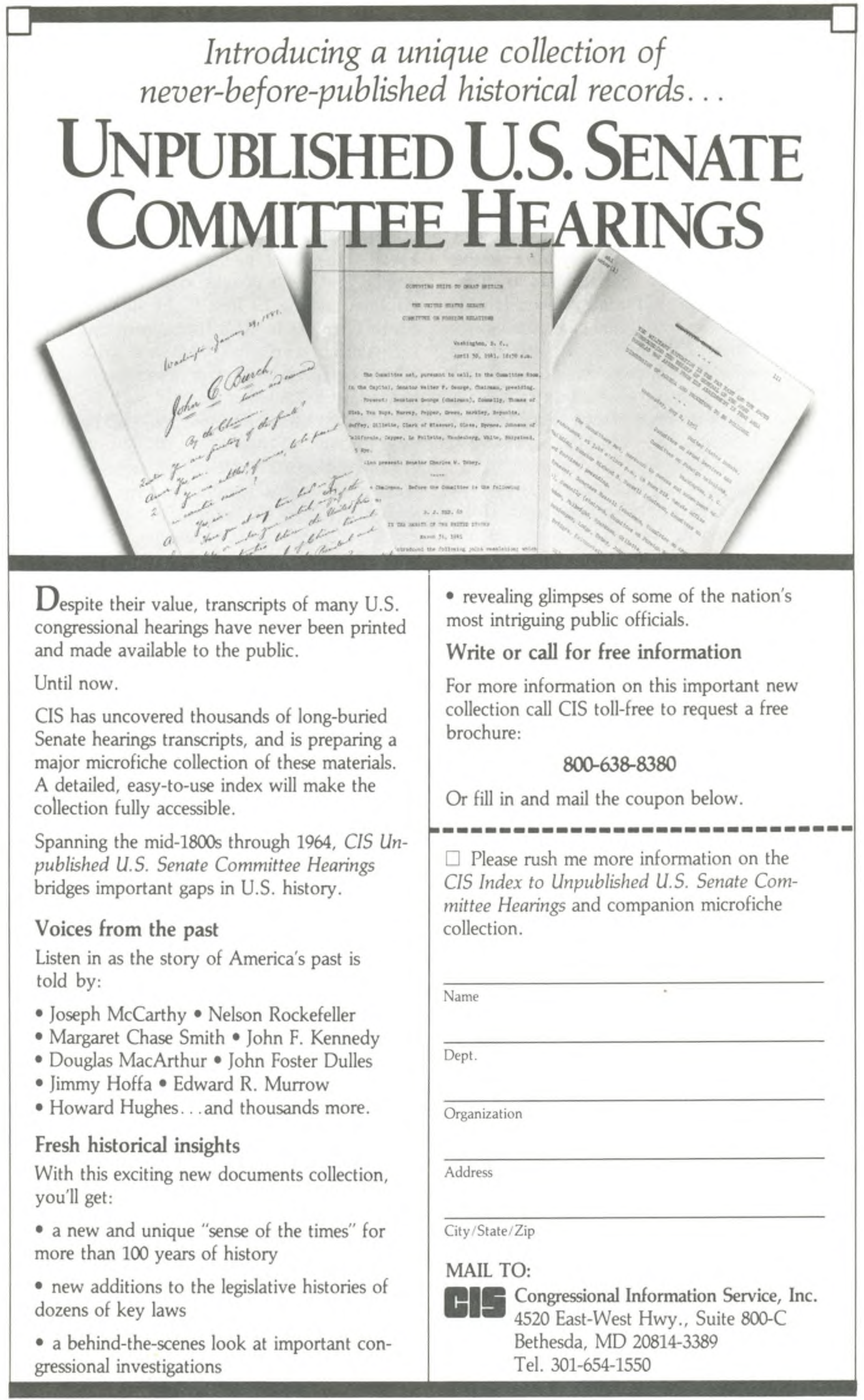


paneled periodicals room has been restored for use as the reading room. Architect Herschel Shepard, whose firm handled the restoration of the old state capital in Tallahassee, was hired by FSU to prepare Dodd Hall for the Pepper Library. Shepard said the reading room was exactly as it was originally built except for the addition of ceiling fans and the substitution, for economic reasons, of slightly different lamps.

Many of Pepper's Congressional papers, as well as his and Mildred's personal papers, are available in this room for students and scholars to study. There are also a variety of finding aids available to users. In addition to traditional card catalogs for books and audiovisual materials, special manuscript registers are used for retrieving unpublished papers. In addition, many of the Library's holdings have been entered on floppy disks-eventually to be converted to hard disk-for quick access when specific items are desired.

The reading room also features a variety of visual displays that chronicle the political and private lives of Claude and Mildred. For example, anyone wishing to view a speech or an interview with Claude Pepper can do so in a special television viewing area.

On the second floor, two rooms have been built to re-create Pepper's Washington offices in the Russell Senate Office Building from 1937 to 1950 , and the Rayburn House Office Building from 1963 to the present. Herschel Shepard made several trips to Washington to measure Pepper's Senate and

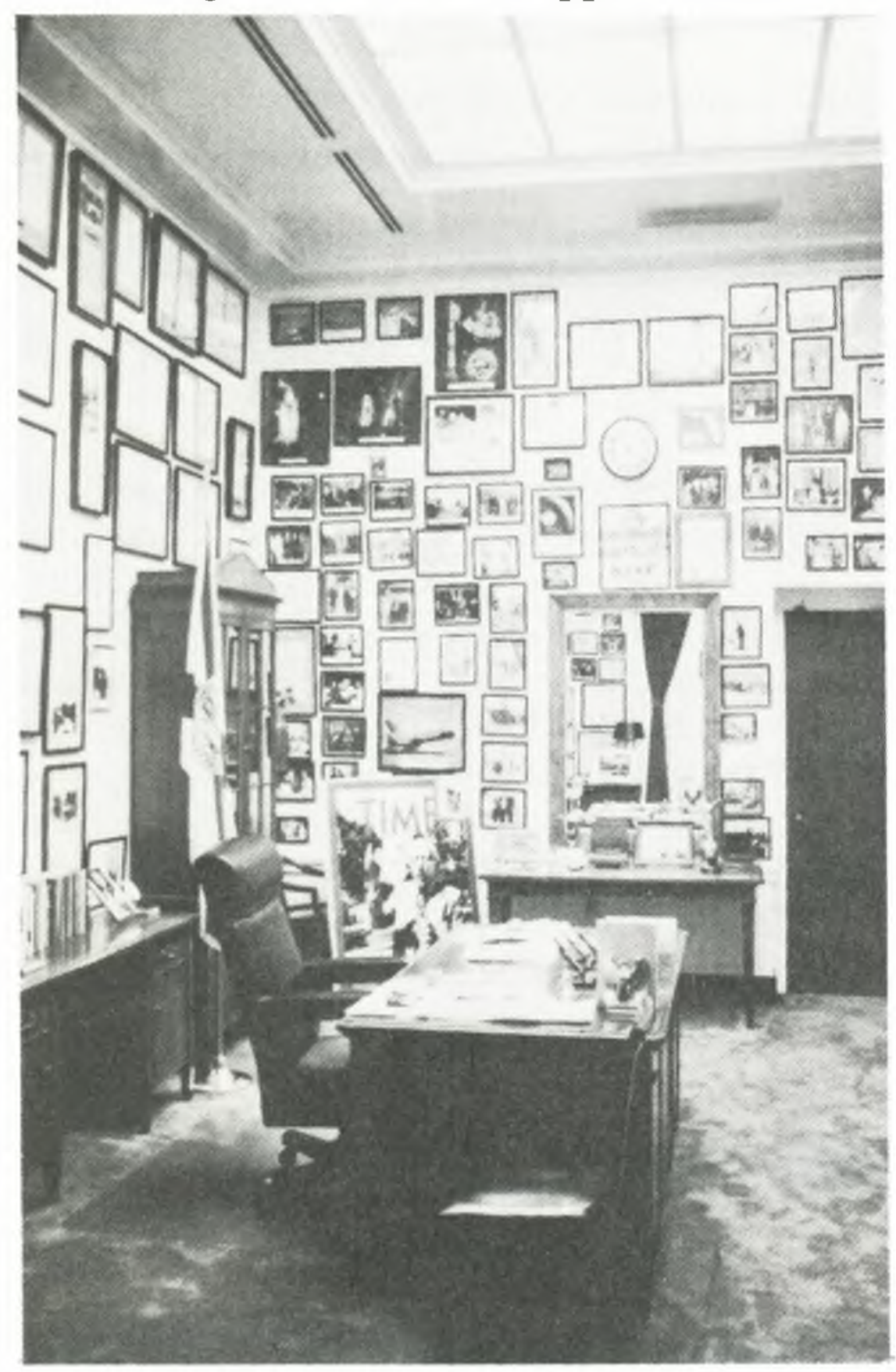

Replicated office of Rep. Claude Pepper, Florida State University.
House offices and studied blueprints provided by the architect of the Capitol before designing and constructing the library rooms. Visitors can walk through and see the rooms just as Pepper worked in them.

His House office, for example, is filled with a remarkable number of framed photographs, plaques, letters, and other mementos that cover his walls from chair rail to ceiling, plus much memorabilia displayed on tables and credenzas. High on a wall to the left of the desk hangs a picture, autographed by Orville Wright, of the Wright brothers' airplane making its first flight at Kitty Hawk, North Carolina in 1903. Just above this historic keepsake hangs a photo of the Apollo 10 lunar module, autographed by its crew, which completed the first walk on the moon in 1969. Such items illustrate the incredible span of history that Pepper has lived through.

Congressman Pepper's staff has collected as much of his original furniture as possible to fill the replicated offices. His restored Senate office, for example, contains his old mahogany Senate desk, which Pepper bought years ago and used in his Miami Law Office. Other souvenirs of those years include a large stuffed rattlesnake given to him by a friend and a clock representing the New Deal era inscribed, "At the Wheel for a New Deal." Photographs from the Pepper Collection showing the Senate office were used to replicate the furnishings. Many photos are hung on the walls in their original grouped arrangements, showing prominent statesmen (presidents, justices, world leaders), Claude and Mildred together on various trips, and the Senate Foreign Relations Committee, on which Pepper so admirably served.

Another curious artifact displayed near the restored offices is an effigy of Pepper, which was hung from an oak on the Capitol lawn in 1940. Nazi sympathizers, angered over his stinging denunciations of the Third Reich, had hung the effigy then tied it to the bumper of a car and dragged it around Capitol Hill. The effigy, which has a coconut head, sawdust for stuffing, and a placard with the words "Claude Benedict Arnold Pepper" on its chest, was kept by Pepper through the years and was restored for display.

The Mildred and Claude Pepper Library, with its research facilities and visual displays housed in a restored scholarly setting, and the replicated offices, offering visitors the opportunity to view Congressman Pepper's working environment, past and present, is indeed unique among other Congressional libraries in the country today. For further information, contact Burt Altman at (904) 6446204.-Burt Altman.

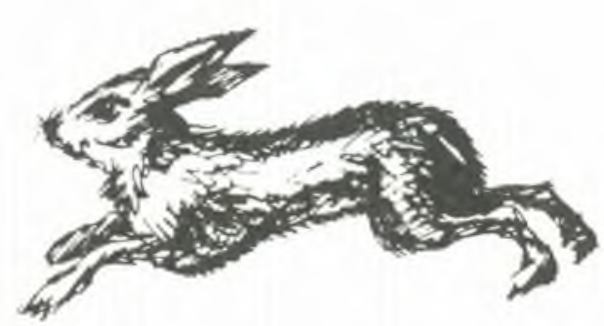

